\title{
Enhancing Productivity and Quality of Annual Cereal Forages through INM: A Review
}

\author{
S. S. Kadam ${ }^{1 *}$, Mohd. Arif ${ }^{2}$, Kavita Chaturvedi ${ }^{3}$ and Mohd. Mohsin ${ }^{3}$ \\ ${ }^{1}$ Mumbai Veterinary College, Mumbai- 400012, Maharashtra, India \\ ${ }^{2}$ ICAR-Central Institute for Research on Goats, Makhdoom, Mathura- 281122, India \\ ${ }^{3}$ Department of Agronomy, Rajasthan College of Agriculture, Udaipur, (Raj), India \\ *Corresponding author
}

\section{A B S T R A C T}

Keywords

Fodder,

feed purchase,

forage cultivation

Article Info

Accepted:

05 April 2020

Available Online:

10 May 2020
Supply of good quality and adequate quantities of fodder play an important role in improving the health and productivity of animals. Green and dry fodders are cheaper sources than concentrate feed, hence its inclusion would curtail the cost of feed purchase. Unfortunately, in our country there is acute scarcity of green and dry fodder mainly due to very less area available for its cultivation. In future also there are less chances to increase area under forage cultivation because of heavy pressure of burgeoning human and livestock population on meager land. Among various improved agro techniques Integrated Nutrient Management (INM) has been proved to be the best options to augment good quality forage production per unit area by sustaining soil fertility and its productivity under limited land resources available today.

\section{Introduction}

Livestock plays an important role in the national economy and in the socio-economic development of the country. It also plays a significant role in the rural economy as supplementing family incomes and generating gainful employment in the rural sector, particularly among the landless labourers, small and marginal farmers and farm women's. The growth in the livestock sector is expected to contribute in the poverty alleviation as nearly 70 percent of livestock market in India is owned by 67 per cent of small and marginal farmers and by the land less poor peoples. The livestock sector contributed over 4.5 per cent to the total GDP during 2015-16 and it's estimated value of the output of Rs. 5,60,613 Crore which is about 25.77 per cent of the value of the total output of Rs.21,75,547Crorefrom agriculture \& 
allied Sector (National Accounts Statistics, 2016). With an estimated 165.4 million tons of annual milk production from 512.1 million livestock, India is the top-most milk producing country in the world and the per capita milk availability is about 355 grams per day as against the recommended requirement of 250 grams (DAHD \& F, 2016).

Although India recorded substantial increase in milk production but the productivity (production per animal) in the country is far less as compared to those in developed dairy nations. There are many reasons but inadequate supply of good quality feed and fodder is the primary cause of lower productivity of milch animals in India (DARE, 2013). Deficiency in feed and fodder is identified as one of the major constraints in achieving desired level of livestock productivity. Further, availability and quality of feed and fodder is increasingly becoming a challenge due to rapidly shrinking land and natural resources and hardly $4.5 \%$ of the cropped area is utilized to grow fodder crops. At present, the country faces a net deficit of $35.6 \%$ of green fodder, $10.95 \%$ of dry crop residues and $44 \%$ of concentrate feed ingredients (IGFRI VISION 2050). The performance of the animals depends on the quantity and quality as well as availability of green fodder at various times during the year (Hatam et al., 2001).

Therefore, there is big challenge before the researchers, strategy makers and scientists to bridge the gap between fodder demand and fodder supply and overcome fodder deficit under declining land resources by adopting various improved agro techniques. Among the various improved agro techniques, Integrated Nutrient Management (INM) is one of the best options for enhancing the forage yield and quality of annual as well as perennial forage crops per unit area. After green revolution due to continuous use of chemical fertilizers we have witnessed detrimental effects on soil, crop, environment and health of human as well as animals. Therefore, judicious use of fertilizers which include chemical fertilizers, organic manures and biofertilizers together in forage production is becoming the need of the day to sustain the fodder production under limited land resources available in our country.

\section{Integrated nutrient management (inm)}

In almost all parts of the India annual cereal fodder crops such as sorghum, maize and pearl millet are mainly grown during kharif season and fodder crops like oat and barley grown during rabi season. Cereal forages are rich in carbohydrates but contain less protein as compare to legume fodders. It has been proved that productivity and quality of these annual cereal forages can be improved by adopting all the nutrient management methods available judiciously (Rasool et al., 2015). Secondly, Integrated Nutrient Management of annual cereal forages has become more essential as these crops don't fix up atmospheric nitrogen like legume crops.

\section{INM in sorghum (Sorghum bicolor)}

In India, fodder sorghum is grown in $2.6 \mathrm{~m}$ ha mainly in western Uttar Pradesh, Haryana, Punjab, Rajasthan and Delhi and fulfills over two third of the fodder demand during Kharif season (Pandey and Roy, 2011).In a field experiment of integrated nutrient management it was observed that green and dry fodder yield of sorghum was significantly higher with the inoculation of Azosprillum however, it had no significant effect on crude protein and crude fibre content in fodder sorghum. Further, it was reported that green and dry fodder yield, crude protein and crude fibre content increased significantly with an increase in the dose of FYM and nitrogen application (Kumar and Sharma, 2002).Field 
experiments conducted at IGFRI,Jhansi for consecutive three years revealed that application of 50 per cent recommended dose of NPK (40:20:0) + vermicompost $5 \mathrm{tha}^{-1}$ + FYM $5 \mathrm{t} \mathrm{ha}^{-1}$ gave significantly higher green fodder, dry matter and crude protein yields of sorghum than other treatments under investigation(Kumar et al., 2004). At Hisar (Haryana) application of 25 per cent $\mathrm{N}$ through FYM along with 75 per cent RDF + Azotobacter recorded significantly higher green fodder and dry matter yield of sorghum over other treatment combinations of organic and inorganic fertilizers, whereas highest crude protein content was recorded with sole application of $15 \mathrm{t} \mathrm{ha}^{-1}$ FYM (Kumar et al., 2008). At PAU, Ludhiana (Punjab) Tiwana and Chaudhary(2009) reported that 100 per cent RDF alone or along with $\mathrm{Zn}$ and INM treatments recorded significantly higher green fodder and dry matter yield of sorghum over control. Shekara et al., (2009) at Mandya (Karnataka) reported that application of 50\% recommended dose of nutrients (RDN) through inorganic fertilizer $+50 \% \mathrm{~N}$ through FYM recorded significantly higher green fodder yield and nutrient use efficiency in sorghum. Further, it was reported that $100 \%$ RDN through inorganic fertilizer + VAM produced highest dry matter yield, crude protein yield, net monetary returns and benefit : cost ratio followed by 50\% RDN through inorganic fertilizer $+50 \% \mathrm{~N}$ through FYM treatment. Application of $75 \mathrm{~kg} \mathrm{~N} \mathrm{ha}{ }^{-1}$ through chemical fertilizer $+25 \mathrm{~kg} \mathrm{~N}^{-1}$ through FYM or castor cake along with the combined inoculation with Azotobacter chroococcum + Azospirillum lipoferum recorded significantly higher green forage yield and crude protein content of forage sorghum in sandy loam soils of Gujarat (Yadav et al., 2010). At Udaipur (Rajasthan) application of recommended dose of fertilizers $\left(80 \mathrm{~kg} \mathrm{~N}+40 \mathrm{~kg} \mathrm{P}_{2} \mathrm{O}_{5} \mathrm{ha}^{-1}\right)$ through inorganic fertilizer along with $25 \mathrm{~kg} \mathrm{ZnSO}$ $\mathrm{ha}^{-1}$ recorded maximum green fodder and dry matter yields of sorghum, which remained at par with $75 \%$ recommended dose of fertilizers along with $2.5 \mathrm{t}$ vermicompost ha ${ }^{-1}$ + Azotobacter + PSB (Kumar et al., 2010).Application of recommended dose of fertilizers through inorganic source along with bio-fertilizer recorded maximum green fodder and dry matter yields of sorghum at Udaipur, Rajasthan (Meena et al., 2010).

\section{INM in maize (Zea mays)}

Maize is one of the most important fodder crops particularly for milch animals. The crop is grown in over 0.9 million ha in different parts of the country throughout the year (Pandey and Roy, 2011).Verma et al., (2006) at Udaipur (Rajasthan) recorded significantly higher plant height, LAI at 60 DAS and grain as well as straw yield with application of $150 \%$ NPK which was statistically at par with 100\% NPK + Azotobacter, 100\% NPK + FYM @10 tha ${ }^{-1}$ and different rate of inorganic fertilizers alone or its combination with $\mathrm{Zn}$ and or S. At Anand (Gujarat) Patel et al., (2007) reported that application of 100 percent Recommended dose of fertilizer +10 t FYM ha ${ }^{-1}$ recorded significantly higher green forage, dry matter and crude protein yield; however, it was it par with 75 per cent recommended dose of fertilizer + 10 t FYM $\mathrm{ha}^{-1}$ for green forage yield.Rasool et al., (2015) reported that application of 75 per cent $(\mathrm{NPK})+\mathrm{FYM}\left(4.5 \mathrm{t} \mathrm{ha}^{-1}\right)+$ bio-fertilizers (Azotobacter+ Phosphate solubilizing bacteria) recorded significantly higher cob yield, dry fodder yield and green biomass yield of maize as compared to other combinations including unfertilized control. At Shimoga (Karnataka)Shilpashree et al., (2012) observed significantly higher straw and grain yields of maize with the application of $100 \% \mathrm{~N}$ through inorganic fertilizers + 7.5 tha $^{-1}$ FYM which was at par with $150 \% \mathrm{~N}$ through inorganic fertilizers +7.5 tha $^{-1}$ FYM, 100\% (50\% N through inorganic 
fertilizers $+50 \% \mathrm{~N}$ through $\mathrm{FYM} /$ vermicompost $), \quad 150 \% \quad(75 \% \quad \mathrm{~N}$ through inorganic fertilizers $+75 \% \mathrm{~N}$ through FYM/vermicompost). In a field experiment conducted at Malaprabha (Karnataka) for consecutive five years application of recommended dose of fertilizer + biofertilizer (Azospirillum $+P S B)$ with one row of sunhemp between two rows of maize (sunhemp incorporated at 45 days after sowing) recorded significantly higher fodder yield and NPK uptake as compared to rest of the treatments. Further, application of 75\% recommended dose of fertilizer + maize stalk incorporation with cellulolytic culture + biofertilizer (Azospirillum $+P S B$ ) and one row of sunhemp between two rows of maize (sunhemp incorporated at 40 days after sowing) recorded at par values of green fodder yield and NPK uptake with $100 \%$ recommended dose of fertilizers during fifth year of experiment (Gundlur et al., 2015). Tetarwal et al., (2011) from Jhalawad (Rajasthan) recorded significantly higher plant height, cobs/plant, grains/cob, grain and biological yield of maize with 150\% RDF which was at par with RDF + 10 tha $^{-1}$ FYM, however significantly higher dry matter at harvest was recorded with RDF + 10 tha ${ }^{-1}$ FYM which was at par with $150 \%$ RDF.

In another experiment it was observed that combined application of $100 \%$ recommended dose of fertilizer + Azotobacter + PSB performed better under agro climatic conditions of Gujarat by recording 58.23 and 52.63 per cent higher green forage and dry fodder yield over other treatments (Jadhav et al., 2018). At Dharwad (Karnataka) significantly higher growth, yield attributes and yield of maize was recorded with sunnhemp + poultry manure @ 1tha ${ }^{-1}+$ $100 \%$ RDN which was at par with sunnhemp + poultry manure @ 1 tha $^{-1}+$ $75 \%$ RDN and cowpea + poultry manure
@ 1 tha $^{-1}+100 \%$ RDN in case of grain and straw yields (Sujatha et al., 2008).

\section{INM in pearl millet (Pennisetum typhoides)}

It is an important forage crop of the arid and semi-arid regions of the country. It is fed to the cattle either as green or dry fodder. Bajra is highly drought tolerant and can grow well in the areas with low rainfall (Pandey and Roy, 2011).At Bichpuri (Agra) in a cropping sequence of pearl millet-wheat it was recorded that combined application of organic manures and fertilizers had significant and positive effects on productivity of the system. The results further indicated that the productivity of the wheat and pearl millet crop can be sustained by the application of balanced use of nutrients to the crops through integration of organic manures and fertilizers (Kumar et al., 2014).

Application of farm yard manure in combination with bio-fertilizer (Azospirillum + PSB) to pearl millet showed significant increase in growth parameters such as plant height, number of leaves plant ${ }^{-1}$ and number of tillers plant ${ }^{-1}$ which in turn increased green fodder yield of $70.7 \mathrm{t} \mathrm{ha}^{-1}$ in hybrids and 87.2 $\mathrm{t} \mathrm{ha}^{-1}$ in composites varieties as compared to control (Basanthi et al., 2012).Golada et al., (2012) reported that application of FYM $10 \mathrm{t}$ $\mathrm{ha}^{-1}$, nitrogen $100 \mathrm{~kg} \mathrm{ha}^{-1}$ and inoculation with Azospirillum to fodder pearl millet recorded significantly higher green forage yield over treatments with their respective lower fertility levels. Further, it was revealed that among different treatment combinations, the treatment $10 \mathrm{t} \mathrm{ha}^{-1} \mathrm{FYM}+100 \mathrm{~kg} \mathrm{~N} \mathrm{ha}^{-1}+$ Azospirillum inoculation recorded significantly higher green forage yield, net return and $\mathrm{B}: \mathrm{C}$ ratio as compared to rest of treatment combinations. At Navsari, (Gujarat) it was observed that application of FYM @ $2.5 \mathrm{t} \mathrm{ha}^{-1}$ along with recommended dose of fertilizer and seed inoculation with 
Azotobacter and phosphorus solubilizing bacteria (PSB) resulted in significantly higher growth characters like plant height and number of tillers plant $^{-1}$ which produced higher dry fodder yield of $7492 \mathrm{~kg} \mathrm{ha}^{-1}$ (Thumar et al., 2016).An experiment of pearl millet -wheat cropping system conducted at CCS HAU, Hisar revealed that highest grain yield of pearl millet followed by wheat was recorded with the application of $100 \%$ recommended dose of NPK in both crops which was at par with $50 \% \mathrm{NPK}+50 \% \mathrm{~N}$ (farmyard manure) to pearl millet and $100 \%$ NPK to wheat and significantly superior over the rest of treatments (Kumar et al., 2005).At Bichpuri (Agra) in a cropping sequence of pearl millet-wheat it was recorded that combined application of organic manures and fertilizers had significant and positive effects on productivity of the system. The results further indicated that the productivity of the wheat and pearl millet crop can be sustained by the application of balanced use of nutrients to the crops through integration of organic manures and fertilizers (Kumar et al., 2014). Patil et al., (2018) from Tirupati reported that application of $75 \%$ RDF + Poultry Manure (PM)@ $2 \mathrm{t} \mathrm{ha}^{-1}+$ Azospirillum @ $5 \mathrm{~kg} \mathrm{ha}^{-1}+$ PSB @ $5 \mathrm{~kg} \mathrm{ha}^{-1}$ produced higher yield attributes (number of earheads $\mathrm{m}^{-2}$, length of earhead, weight of grains earhead ${ }^{-1}, 1000$ grain weight), yield (Grain yield, stover yield and harvest index) and quality parameters (protein, carbohydrate) in pearlmillet. However, it was comparable with application of $75 \% \mathrm{RDF}+\mathrm{FYM} @ 5 \mathrm{t} \mathrm{ha}^{-1}+$ Azospirillum@5 kg ha ${ }^{-1}+$ PSB @ $5 \mathrm{~kg} \mathrm{ha}^{-1}$. Application of $50 \%$ RDF + FYM @ $7.5 \mathrm{tha}$ 1 , registered the lowest values of yield attributes, yield and quality parameters.

\section{INM in oat (Avena sativa L.)}

Oat locally known as jai, is one of the most important dual purpose winter cereal crop grown for animal food and grain production under irrigated conditions of northern and north-western regions of India (Pandey and Roy, 2011). During the experiment at Assam it was found that application of 50 per cent recommended dose of fertilizers $+2.5 \mathrm{t}$ ha ${ }^{1}$ Vermicompost $+2.5 \mathrm{t} \mathrm{ha}^{-1} \mathrm{FYM}$ gave the highest green forage yield, dry matter yield and net return per rupee invested (Sharma et al., 2004).Application of 50 per cent recommended dose of fertilizers + vermicompost $5 \mathrm{t} \mathrm{ha}^{-1}+$ FYM $5 \mathrm{t} \mathrm{ha}^{-1}$ produced significantly higher green fodder and dry matter yield of oat than other treatments except 50 per cent recommended dose of fertilizers either with vermicompost or FYM @ $5 \mathrm{t} \mathrm{ha}^{-1}$ (Sheoran et al., 2005 ).

Kumar and Shivadhar (2006) at Jhansi observed that application of 50 per cent recommended dose of NPK, vermicompost $5 \mathrm{t}$ $\mathrm{ha}^{-1}$ and FYM $5 \mathrm{t} \mathrm{ha}{ }^{-1}$ may be adopted for getting higher, sustainable and quality fodder from single cut oat under irrigated conditions. Godara et al., (2012) reported that higher green herbage, dry matter yield and quality of oat could be obtained with integration of either vermicompost@5 tha ${ }^{-1}$ or FYM @10 $\mathrm{t} \mathrm{ha}^{-1}$ and Azotobacter with 75 per cent of recommended dose of fertilizer resulted in saving of 25 per cent chemical fertilizers. At Srinagar, Khanday et al., (2009) reported that application of $20 \mathrm{t}$ FYM ha ${ }^{-1}$ and $60 \mathrm{~kg} \mathrm{P}_{2} \mathrm{O}_{5}$ $\mathrm{ha}^{-1}$ have marginal effect on seed yield and straw yield, than $15 \mathrm{t} \mathrm{FYM} \mathrm{ha}^{-1}$ and $40 \mathrm{~kg}$ $\mathrm{P}_{2} \mathrm{O}_{5} \mathrm{ha}^{-1}$. However, the application of $15 \mathrm{t}$ FYM ha ${ }^{-1}$ and $40 \mathrm{~kg} \mathrm{ha}^{-1}$ were economically feasible. Application of $10 \mathrm{~kg} \mathrm{Zn} \mathrm{ha}{ }^{-1}$ was better both with respect to productivity and economically than no zinc application. At West Bengal, Hembram and Kundu (2016) reported that higher green forage and dry matter yield of oat were recorded with the application of GM $+25 \%$ N FYM $+50 \%$ NPK inorganic. But higher crude protein was recorded with the application of GM $+25 \% \mathrm{~N}$ $\mathrm{FYM}+50 \%$ Biofertilizer which is 
statistically at par with GM $+25 \% \mathrm{~N}$ FYM + $50 \%$ NPK inorganic and GM $+50 \%$ N FYM + PSB + Biofertilizer. At Bichpuri (Agra) maximum values of growth, yield attributes, green foliage yield and dry matter yield were recorded with $75 \% \mathrm{NPK}+5 \mathrm{t}$ FYM $+20 \mathrm{~kg} \mathrm{~S}$ $\mathrm{ha}^{-1}$ closely followed by $75 \% \mathrm{NPK}+5 \mathrm{t}$ FYM $+10 \mathrm{~kg} \mathrm{Mn} \mathrm{ha}{ }^{-1}$. Further, the uptake of N, P, $\mathrm{K}, \mathrm{S}, \mathrm{Fe}, \mathrm{Cu}$ and $\mathrm{Zn}$ by oat crop was highest at $75 \% \mathrm{NPK}+5 \mathrm{t} \mathrm{FYM}+20 \mathrm{~kg} \mathrm{~S} \mathrm{ha}^{-1}$ and lowest in control. The amounts of available $\mathrm{N}$, $\mathrm{P}$ and $\mathrm{K}$ in post-harvest soil were maximum with the application of $100 \%$ NPK but organic carbon, sulphur and iron, were maximum with the $75 \% \mathrm{NPK}+5 \mathrm{t} \mathrm{FYM}+20$ $\mathrm{kg} \mathrm{S} \mathrm{ha}{ }^{-1}$ and $\mathrm{Cu}$ and $\mathrm{Zn}$ with $75 \% \mathrm{NPK}+5 \mathrm{t}$ FYM $+10 \mathrm{~kg} \mathrm{Mn} \mathrm{ha}{ }^{-1}$. The minimum amounts of available nutrients in post-harvest soil were recorded under control treatment (Pandey, 2018).

\section{INM in barley (Hordeum vulgare)}

Barley is generally grown in areas where irrigation facilities are limited, as it can tolerate moisture and salt stress to a great extent (Yadav et al., 2003).At Bichpuri, Agra maximum values of number of effective shoots/m, spike length, number of spikelets/spike, number of fertile spikelets/spike, number of grains/spike, weight of grains/spike, 1000-grain weight, grain yield and straw yield were recorded at 75 per cent $\mathrm{NPK}+5$ t $\mathrm{FYMha}^{-1}$ +biofertilizer over lower levels of NPK and control (Singh and Chauhan, 2016). Tomar et al., (2016) recorded significant improvement in ear length, grains ear $^{-1}$, effective ears $\mathrm{m}^{-1}$, test weight, grain, straw and biological yields with the application of RDF + bio-fertilizer + FYM $\left(5 \mathrm{t} \mathrm{ha}^{-1}\right)$ as compared to rest of the fertility levels. Dinka et al., (2018) from Ethopia reported that integrated nutrient management significantly improved yield and yield components of barley. The phenological and growth parameter of barley were improved with application of integrated nutrient management. Higher biomass and grain yield of barley were obtained from application of 66.6:33.4\% NPS: FYM. According to Bhakher et al., (1997) application of FYM @ $10 \mathrm{t} \mathrm{ha}^{-1}$ significantly increased the protein content in barley grains and total nitrogen uptake by 3.6 and 28.9 per cent, respectively over control. At Bichpuri, Agra, the maximum values of plant height, dry matter accumulation, effective tillers $\mathrm{m}^{-1}$, spike length, spikelets spike $^{-1}$, fertile spikelets spike $^{-1}$, grains spike ${ }^{-1}$, test weight, grain and straw yield of barley were recorded at $75 \%$ $\mathrm{NPK}+5 \mathrm{t}$ FYM ha ${ }^{-1}+$ biofertilizer and minimum in control. However, the maximum protein contents in grain and straw were recorded with $100 \%$ NPK alone. Further, the integrated use of chemical fertilizers and FYM improved the starch content in grain and maximum value was recorded with $75 \%$ NPK $+5 \mathrm{t} \mathrm{FYM} \mathrm{ha}^{-1}+$ biofertilizer.

The uptake of $\mathrm{N}, \mathrm{P}$ and $\mathrm{K}$ by grain and straw of barley was found to be associated with production of grain and straw resulted by the addition of $75 \%$ NPK +5 t FYM ha ${ }^{-1}+$ biofertilizer (Singh, 2017).Ram and Dahliwal (2012) reported that in the two years of experiment at PAU, Ludhiana (Punjab) the highest productivity of barley was recorded in 75 per cent RDF + FYM in first year and in 75 per cent RDF + FYM + biofertilizer in second year which was statistically at par with 75 per cent RDF + FYM + biofertilizer in first year and 75 per cent RDF + FYM treatments in second year but significantly higher than rest of the treatments. Tufa et al., (2018) from Ethopia reported that significantly higher grain yield and biomass yield of barley were obtained with the application of sole recommended NP and the integrated use of $50: 50 \%$ vermicompost and conventional compost with recommended NP. The economic analysis confirmed the profitability of the integrated use of $50: 50 \%$ conventional 
compost and vermicompost with recommended NP fertilizer for barley production. Kumawat (2003) recorded significantly higher $\mathrm{N}, \mathrm{P}, \mathrm{K}$ concentration in grain and straw and their uptake and protein content in barley due to application of organic manures. Vermicompost @ $4.5 \mathrm{t} \mathrm{ha}^{-1}$ was found to be superior to other treatments and recorded a protein content of $11.53 \%$.

Due to mounting pressure of burgeoning human and livestock population on limited land in future also there is least chance to bring more arable land under forage cultivation .Hence, for achieving fodder and nutritional security every piece of available land should be efficiently utilized and managed by adopting modern agro techniques like Integrated Nutrient Management. It could be concluded that productivity as well as quality of annual forage crops can be improved through judicious fertilizer management. This agronomic strategy will reduce the present wide gap between fodder demand and fodder supply at some extent by providing better forage yield and nutritious fodders per unit area per unit time and thereby help to improve health as well as productivity of our animals.

\section{References}

Basanthi, C., Biyan, S. C., Dhuppar, P. andRao, D. S. 2012.Integrated nutrient management impact on performance of hybrid and composite cultivars of pearl millet (Pennisetumglaucum).Forage Research38: 102-105.

Bhakher, J. R., Sharma, O. P. and Jat, B. C. 1997. Effect of nitrogen and FYM on yield and yield attributes of barley (Hordeumvulgare L.) in a loamy sand soil. Annals of Agricultural Research 18: 244-245.

DAHD \& F. 2016.Department of Animal Husbandry, Dairying \& Fisheries,
Ministry of Agriculture, Government of India.

DARE. 2013. Department of Agricultural Research and Education, Ministry of Agriculture, Government of India. DARE Report (January-March).

Dinka, T. B, Goshu, T. A. and Haile, E. H. 2018. Effect of Integrated Nutrient Management on Growth and Yield of Food Barley (Hordeumvulgare) Variety in Toke Kutaye District, West Showa Zone, Ethiopia. Advances in Crop Science and Technology 6 (3): 1-8. doi: 10.4172/2329-8863.100036

Godara, A. S., Gupta, U. S. and Singh, R. 2012.Effect of integrated nutrient management on herbage, dry fodder yield and quality of oat (Avena sativa L.).Forage Research, 38: 59-61.

Golada, S. L., Sharma, G. L., Verma, A. and Jain, H. K. 2012.Effect of FYM, Nitrogen and Azospirillumon on Yield, Economics and Soil Nutrient Status of Forage Pearl Millet.Madras Agricultural Journal99 (4-6): 308-310.

Gundlur, S. S., Patil, P. L. Rajkumara, S. Ashoka, P. and Neelakantha, J. K. 2015. Influence of integrated nutrient management on yield and uptake of nutrients by maize and soil fertility under irrigated conditions in Vertisol. Karnataka Journal of Agricultural Sciences28 (2): 172-175.

Hatam, M., Akmal, M., Habib, G. and Siddiqui, M. 2001. Status paper on establishment of fodder and forage discipline. NWFP Agriculture University Peshawar.pp.105.

Hembram, J. and Kundu, C. P. 2016.Effect of integrated nutrient management on growth, yield and quality of forage cropping sequence.Journal of Agricultural Science and Research 3(1): 17-22

IGFRI Vision. 2050. Indian Grassland and Fodder Research Institute, Jhansi (UP) - 
284003.

http://144.16.140.129/Vision\%202050

\%20IGFRI,\%20Jhansi.pdf

Jadhav, V. M., Patel, P. M., Chaudhari, J. B., Patel, J. M. and Chaudhari, P. P. 2018. Effect of Integrated Nutrient Management on growth and yield of rabi forage maize (Zea mays L.). International Journal of Chemical Studies 6(1): 2160-2163.

Khanday, B. A., Samoon, A. R., Raja, W., Khanday, J. and Bahar, F. A. 2009. Integrated nutrient management for seed production of oat (Avena sativa L.) under temperate conditions of Kashmir.International Journal of Agricultural Sciences, 5 (1): 145-147.

Kumar, A., Rana, D. S. and Sheoran, R. S. 2008.Effect of integrated nutrient management on forage yield and quality of sorghum [Sorghum bicolor (L.)Moench].Forage Research 34 (3): 165-169.

Kumar, P. O., Nanwal, R. K. and Yadav, S. K. 2005. Integrated nutrient management in pearl millet (Pennisetum glaucum)-wheat (Triticum aestivum) cropping system. Indian Journal of Agricultural Sciences 75(10): 640-643.

Kumar, P., Singh, R., Singh, A., Paliwal, D. and Kumar, S. 2014. Integrated nutrient management in pearl millet (Pennisetumglaucum) - $\quad$ wheat (Triticumaestivum) cropping sequence in semiarid condition of India. International Journal of Agricultural Science 10(1): 96-101.

Kumar, R., Singh, P. and Sumeriya, H. K. 2010.Effect of integrated nutrient management on growth and productivity of forage sorghum (Sorghum bicolar(L.)Moench).Forage Research36(1): 19-21.

Kumar, S. and Sharma, B. L. 2002.Effect of FYM, nitrogen and Azospirillum inoculation on yield and quality of fodder sorghum. Forage Research 28(3): 165- 168.

Kumar, S. and Shivadhar. 2006. Influence of organic and inorganic sources of nutrients on forage productivity and economics of oat (Avena sativa L.). Annalsof Agricultural Research27: 205209.

Kumar, S., Rawat, C. R., Singh, K. and Melkania, N. P. 2004.Effect of integrated nutrient management on growth, herbage productivity and economics of forage sorghum [sorghum bicolor (L.)Moench].Forage Research 30 (3): 140-144.

Kumawat, P. D. 2003. Response of barley to organic manure and nitrogen fertilization.PhD. Thesis. RAU, Bikaner.

Meena, R. M., Dashora, L. N., Singh, P. and Sumeriya, H. K. 2010. Effect of integrated nutrient management on yield and quality of single cut forage sorghum (Sorghum bicolar(L.) Moench).Forage Research36(1): 61-63.

National Accounts Statistics. 2016. Central Statistical Organization, Government of India.

Pandey, K. C. and Roy, A. K. 2011. Forage crops varieties, IGFRI, Jhansi: 1-16.

Pandey, M. 2018. Effect of integrated nutrient management on yield, quality and uptake of nutrients in oat (Avena sativa) in alluvial soil.Annals of Plant and Soil Research 20(1): 1-6.

Patel, A. S., Sadhu, A. C., Patel, M. R. and Patel, P. C. 2007.Effect of Zinc, FYM and Fertility levels on yield and quality of forage maize (Zeamays L.).Forage Research 32 (4): 209-212.

Patil, P., Nagamani, C., Reddy, A. P. K. and Umamahesh, V. 2018.Effect of integrated nutrient management on yield attributes, yield and quality of pearl millet [Pennisetum glaucum (L.)R. br.emend.stuntz]. International Journal 
of Chemical Studies 6(4): 1098-1101.

Ram, H. and Dhaliwal, S. S. 2012.Effect of varieties and integrated nutrient management techniques on growth, productivity, quality and economics of barley (Hordeum vulgare L.). International Journal of Agricultural Sciences 8(1): 91-97.

Rasool, S., Kanth, R. H., Hamid, S., Raja, W., Ali, B. A. and Dar, Z. A. 2015. Influence of integrated nutrient management on growth and yield of sweet corn [Zea mays (L.) saccharata] under temperate conditions of Kashmir Valley. American Journal of Experimental Agriculture 7: 315-325.

Sharma, K. K., Sharma, S. and Neog, S. B. 2004. Integrated Nutrient Management in oat (Avena sativa L.). Forage Research, 29 (4): 195-197

Shekara, B. G., Lohithaswa, H. C. and Pavan, R. 2009.Effect of different sources of nutrients on green forage yield and quality of multicut fodder sorghum [Sorghum bicolor (L.)Moench].Forage Research 35 (3): 137-142.

Sheoran, R. S., Rana, D. S. and Singh, K. P. 2005. Integrated Nutrient Management for sustainable fodder yield of oat (Avena sativa L.) under semi-arid conditions. Forage Research 31 (2): 126-129.

Shilpashree, V. M., Chidanandappa, H. M., Jayaprakash, R. and Punitha, B. C. 2012.Influence of Integrated Nutrient Management Practices on Productivity of Maize Crop.Indian Journal of Fundamental and Applied Life Sciences 2(1): 45-50.

Singh, S. B. 2017. Effect of integrated nutrient management on barley (Hordeumvulgare L.) under north western plain zone of Uttar Pradesh.Annals of Plant and Soil Research 19(1): 110 - 114.

Singh, S. B. and Chauhan, S. K. 2016.Effect of integrated nutrient management on barley (Hordeumvulgare L.) under semi-arid conditions of western Uttar Pradesh.Technofame5: 20-23.

Sujatha, M. G., Lingaraju, B. S., Palled, Y. B. and Ashalatha, K. V. 2008. Importance of integrated nutrient management practices in maize under rainfed condition. Karnataka Journal of Agricultural Science 21(3): 334-338.

Tetarwal, J. P., Baldev, R. and Meena, D. S. 2011. Effect of integrated nutrient management on productivity, profitability, nutrient uptake and soil fertility in rainfed maize (Zea mays).Indian Journal of Agronomy 56(4): 373-376.

Thumar, C. M., Dudhat, M. S., Chaudhari, N. N., Hadiya, N. J. and Ahir, N. B. 2016. Growth, Yield attributes Yield and Economics of Summer Pearl Millet (PennisetumglaucumL.) as influenced by Integrated Nutrient Management. International Journal of Agriculture Sciences 8 (59): 3344-3346.

Tiwana, U. S. and Chaudhary, D. P. 2009. Effect of integrated nutrient management on the yield and quality of forage sorghum. Forage Research 35: $56-58$.

Tomar, J., Kumar, P., Kumar, A., Kumar, A., Sandhya, Kumar, S. and Kushwaha, S. R. 2016. Influence of irrigation schedules and fertilizer levels on barley (Hordeumvulgare) in western Uttar Pradesh. Indian Journal of Agronomy 61(4): 515-518.

Tufa, T., Midega, T., Kumbi, H. and Tola, B. 2018.Effect of Integrated Inorganic and Organic Fertilizers on Yield and Yield Components of Barley in LibenJawi District. International Journal of Agronomyhttps://doi.org/10.1155/2018/ 2973286

Verma, A., Nepalia, V. and Kanthaliya, P. C. 2006. Effect of integrated nutrient 
supply on growth, yield and nutrient uptake by maize (Zea mays)-wheat (Triticumaestivum) cropping system. Indian Journal of Agronomy 51(1): 3-6.

Yadav, P. C., Sadhu, A. C., Swarnakar, P. K. and Patel, M. R. 2010.Effect of integrated nitrogen management on forage yield of multicut sorghum, available nitrogen and microbial count in the soil.Journal of the Indian Society of Soil Science58: 303-308.

Yadav, R. K., Kumar, A. and Lal, D. 2003. Effect of cutting management and nitrogen levels on biomass production and proximate quality of barley (HordeumvulgareL.) in saline soil.Indian Journal of Agronomy 48: 199-202.

\section{How to cite this article:}

Kadam. S. S., Mohd. Arif, Kavita Chaturvedi and Mohd. Mohsin. 2020. Enhancing Productivity and Quality of Annual Cereal Forages through INM: A Review. Int.J.Curr.Microbiol.App.Sci. 9(05): 206-215. doi: https://doi.org/10.20546/ijcmas.2020.905.024 